Мохова Юлія Леонідівна кандидат наук 3 державного управління, доцент магістратури державного управління Центру післядипломної освіти, Донецький національний технічний університет, пл.Шибанкова, буд.2, м.Покровськ, 85300, тел.: (062) 392-03-09, e-mail: julimokhova@gmail.com, https://orcid.org/0000-0002-0093-2620.

Орлова Наталія Сергіївна доктор наук 3 державного управління, професор, професор кафедри державного управління, публічного адміністрування та регіональної економіки, Харківський національний економічний університет імені Семена Кузнеця, пр. Науки, 9А, м.Харків, 61166, тел.: (057) 702-18-37. e-mail: nsorlova78@gmail.com, https://orcid.org/0000-0003-0785-751x

\title{
РОЛЬ ЦИФРОВИХ КОМПЕТЕНТНОСТЕЙ У ФОРМУВАННІ ЦІФРОВОГО СУСПІЛЬСТВА
}

Анотація. В умовах постійного інноваційного розвитку, впровадження інформаційно-комунікаційних технологій, цифрової трансформації формуються нові вимоги до цифрової компетентності працівників публічного управління. Метою статті $є$ визначити роль цифрових компетентностей в розвитку держаних службовців та посадових осіб в органах державної влади та місцевого самоврядування для формування ефективної взаємодії уряду, суспільства та бізнесу. Доведено. що компетенція в сфері цифрових технологій повинна сприйматися як технічні знання та знання в когнітивних, соціальних та емоційних аспектах роботи в цифровому середовищі. Узагальнено ключові навички в сфері цифрових технологій. Виділено основні напрямки компетенції в сфері цифрових технологій (вирішення проблеми, самоврядування, робота 3 людьми, використання технологій та їх розробка).

Доведено, що галузь цифрових навичок і компетенцій є однією 3 найбільш неврегульованих в сфері гармонізації цифрових ринків через наявність таких проблем, як відсутність обліку високотехнологічної продукції, цифровізованих послуг, відсутність використання органами державної влади автоматизованих систем діловодства, відсутність наскрізних систем електронного документообігу, недостатній рівень розвитку концепції «мобільних» державних службовців 3 відповідними інструментами ефективної дистанційної роботи.

Виділено ключові компонентості трансформацій в організаціях публічного сектору (віддане лідерство, переконлива комунікація, чітка ціль та пріоритети, спроможності до впровадження змін, злагодженість та координація у впровадженні). Визначено основні заходи для реалізації 
стратегії цифровізації: масштабне використання IКТ та цифрових технологій; формування новітнього дизайну навчального простору; модернізація інфраструктурного оснащення; впровадження нових технологічних i управлінських рішень; використання технології онлайн-навчання із застосуванням цифрових освітніх ресурсів, створення цифрової екосистеми для держаних службовців та посадових осіб в органах державної влади та місцевого самоврядування.

Ключові слова: цифрові навички, цифрова компетентність, публічний сектор, цифровізація.

Mokhova Yuliya Leonidivna Candidate of Sciences in Public Administration, Associate Professor of Master of Public Administration of the Center for Postgraduate Education, Donetsk National Technical University, Shibankova Square, building 2, Pokrovsk, 85300, tel.: (062) 392-03-09, e-mail: julimokhova@gmail.com, https://orcid.org/0000-0002-0093-2620.

Orlova Natalia Sergeevna Doctor of Science in Public Administration, Professor, Professor of the Department of Public Administration, Public Administration and Regional Economy, Semyon Kuznets Kharkiv National University of Economics, 9A Nauki Ave., Kharkiv, 61166, tel .: (057) 702-18-37 e-mail: nsorlova78@gmail.com, https://orcid.org/0000-0003-0785-751x

\title{
THE ROLE OF DIGITAL COMPETENCIES IN THE FORMATION OF THE DIGITAL SOCIETY
}

\begin{abstract}
In the conditions of constant innovative development, introduction of information and communication technologies, digital transformation new requirements to digital competence of employees of public administration are formed. The aim of the article is to determine the role of digital competencies in the development of civil servants and officials in public authorities and local selfgovernment for the formation of effective interaction between government, society and business. Brought. that competence in digital technology should be perceived as technical knowledge and expertise in the cognitive, social and emotional aspects of working in a digital environment. The key skills in the field of digital technologies are generalized. The main areas of competence in the field of digital technologies are identified (problem solving, self-government, work with people, use of technologies and their development).

It is proved that the field of digital skills and competencies is one of the most unregulated in the field of harmonization of digital markets due to such problems as lack of accounting for high-tech products, digitalized services, lack of use of automated office systems, lack of end-to-end electronic document management systems. the concept of «mobile» civil servants with appropriate tools for effective remote work.
\end{abstract}

The key components of transformations in public sector organizations are highlighted (committed leadership, convincing communication, clear goal and 
priorities, ability to implement changes, coherence and coordination in implementation). The main measures for the implementation of the digitalization strategy are identified: large-scale use of ICT and digital technologies; formation of the newest design of educational space; modernization of infrastructure equipment; introduction of new technological and managerial solutions; use of online learning technology with the use of digital educational resources, creation of a digital ecosystem for civil servants and officials in public authorities and local governments.

Keywords: digital skills, digital competence, public sector, digitalization.

Постановка проблеми. В умовах постійного інноваційного розвитку, впровадження інформаційно-комунікаційних технологій, цифрової трансформації формуються нові вимоги до рівня компетенцій працівників публічного управління, в тому числі рівня їх цифрової компетентності. Цифрова компетентність передбачає спроможність здійснювати професійну діяльність у поєднанні з якостями, що дозволяють діяти самостійно. Активне використання цифрових технологій сприяе ефективності виробничого процесу на всіх рівнях i формуванню професійних компетентностей майбутніх фахівців.

Вирішальне практичне значення має наявність належних цифрових компетенцій для кожного. Формування професійних спеціалістів 3 компетентісним підходом до своєї професії виступає гарантією та інструментом сучасних перетворень у цифровому суспільстві, в основі яких цінність інтелектуальної власності, знань, інформації. Відповідно до умов мінливого середовища дослідження цифрової компетентності потребують доповнення та удосконалення.

Аналіз останніх досліджень і публікацій. До авторів, які вивчали питання цифровізації як явища, відносять Архипова Є.О. [1], Майло В.В. [2], Олексюк Л. В. [3], Орлова Н.С. [2, 4]. Дослідження вчених мають практичне та теоретичне значення, проте проблема формування та розвитку цифрових компетентностей, як важливої складової забезпечення ефективного управління організацією в умовах динамічного середовища, потребує постійного вивчення.

Метою статті є визначити роль цифрових компетентностей в розвитку держаних службовців та посадових осіб в органах державної влади та місцевого самоврядування для формування ефективної взаємодії уряду, суспільства та бізнесу.

Виклад основного матеріалу. Розвиток цифрових навичок найважливіша умова для розвитку цифрового суспільства будь-якої країни, оскільки прямо або опосередковано пов'язаний 3 усіма сферами функціонування суспільства та економіки.

Цифрові навички також вважаються вихідною рамковою умовою для розвитку всіх інших пріоритетів у сфері гармонізації цифрових ринків країн Європейського союзу (СС) та Східного Партнерства, визначених під час засідання на рівні міністрів на тему «Цифрова спільнота» (2016 рік, 
Брюссель), концентруючись на ключових пріоритетах та конкретних досягненнях [5].

Цифрова компетентність - багатогранний еволюціонуючий процес, що постійно змінюється при появі нових технологій [6].

Компетенція в сфері цифрових технологій повинна сприйматися не лише як знання, що мають відношення до технічних навичок, але і як знання, більшою мірою зосереджені на когнітивних, соціальних та емоційних аспектах роботи і життя в цифровому середовищі.

За прогнозами Світового Економічного Форуму до 2025 року 50 \% усіх працівників потребуватимуть перенавчання, адже економіки світу переживають подвійне потрясіння - пандемію та стрімку автоматизацію праці. Передбачають, що 85 млн. робочих місць у продовж наступних 5 років можуть замінити машини. Водночас 97 млн. нових робочих місць можуть 3’явитися у процесі адаптації ринку праці до нових реалій.

Наразі до топ-10 навичок відносять використання технологій, моніторинг та контроль; аналітичне мислення та інновації; активне навчання та навчальні стратегії; комплексне вирішення проблем; критичне мислення та аналіз; креативність, оригінальність та ініціативність; лідерство та соціальний вплив, дизайн технологій та програмування; стійкість, стресостійкість та гнучкість; вміння аргументувати, вирішувати проблеми та створювати ідеї. Таким чином основними напрямками $\epsilon$ вирішення проблеми, самоврядування, робота з людьми, використання технологій та їх розробка.

Дані щодо розвитку цифровізації у різних сферах публічного управління за «Національною економічною стратегією на період до 2030 року» свідчать про недостатній рівень цифрових навичок та цифрових навичок користувачів. Для того, щоб система стратегічних комунікацій в органах публічної влади в Україні була ефективною, необхідно постійно вдосконалювати іiі технологічне забезпечення, нормативно-правові акти щодо внутрішньої бази даних за всіма контрагентами у системі комунікацій, врегулювати процеси оприлюднення та оновлення інформації, підвищити рівень цифрових компетентностей користувачів.

Відсутність ефективної системи регулювання зменшує потенціал України на одному з найдинамічніших цифрових ринків. Новизна технології та низький рівень іï регулювання в ЄС створює можливості для України стати однією з перших у галузі в Європі. Офіційна статистика не визначає обсягу цифрової економіки в Україні.

Методика збору статистичних даних державними органами статистики $є$ далеко недосконалою для проведення належного аналізу ситуації в сфері розвитку цифрових навичок i компетенцій. Таким чином, дана галузь $\epsilon$ однією з найбільш неврегульованих в сфері гармонізації цифрових ринків[7].

Не ведеться облік високотехнологічної продукції, цифровізованих послуг, використання органами державної влади автоматизованих систем діловодства, відсутність наскрізних систем електронного документообігу. Недостатній рівень розвитку концепції «мобільних» державних службовців 3 
відповідними інструментами ефективної дистанційної роботи [4].

Треба звернути увагу на необхідність матеріальних, технічних та фінансових ресурсів для ефективного функціонування інформаційного простору та розробити критерії оцінки інформаційно-комунікаційних технологій для органів публічного управління. Також, серед працівників органів державної влади та місцевого самоврядування мають бути фахівці, які здатні координувати впровадження механізмів та комплексної системи електронного урядування в органах державної влади, а також вести постійний супровід цієї системи, що потребує якісної спеціальної та професійно-галузевої підготовки кадрів для державної служби та служби в органах місцевого самоврядування [1].

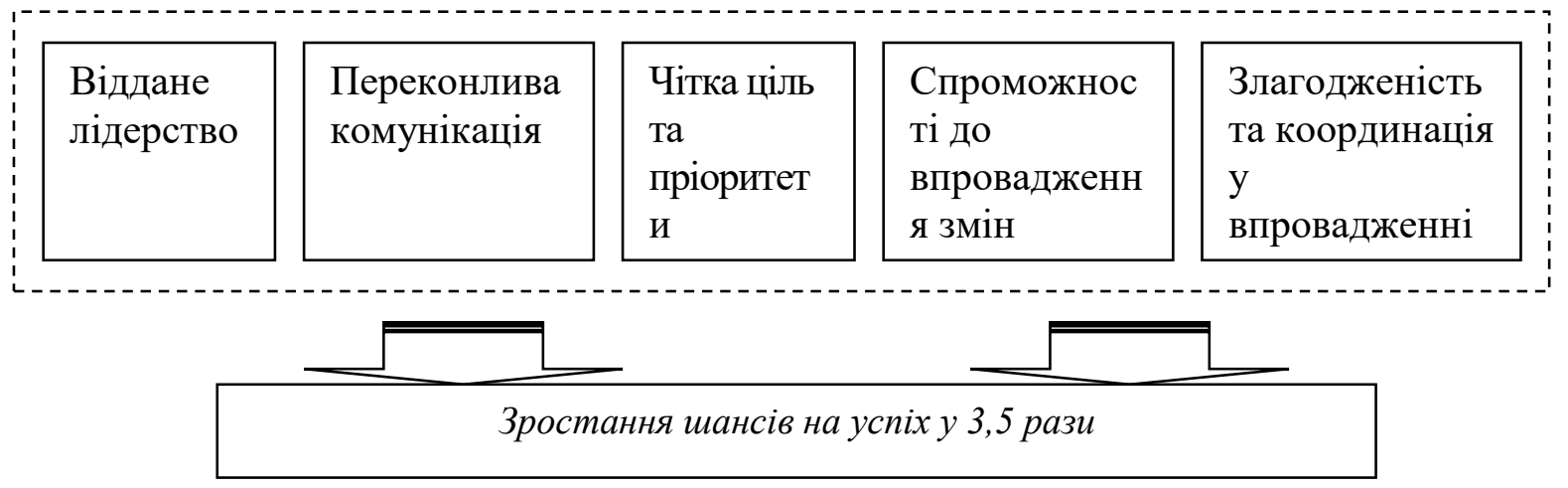

Рис. 1. Ключові компоненти трансформаџій в організаціях публічного сектору [8]

3 метою виконання пункту 63 Плану заходів протягом 2020 року представниками Міністерство цифрової трансформації України організовано та проведено 38 вебінарів для представників центрів надання адміністративних послуг (ЦНАП). Для участі у вказаних вебінарах запрошено представників інших центральних органів виконавчої влади, експертів у різних сферах діяльності. Статистика переглядів вказаних заходів складає понад 61 тис. Місцевими державними адміністраціями надано інформацію щодо проведення понад 240 навчальних та інформаційних заходів для 3780 учасників щодо покращення якості надання адміністративних послуг, а також роботи центрів надання таких послуг. Основними темами відповідних заходів були: трансформація ЦНАП; впровадження та робота 3 програмним комплексом «Соціальна громада»; організація роботи фронт-офісів соціального захисту населення в громадах; управління конфліктами в сервісних організаціях; запровадження комплексної послуги єМалятко; співробітництво територіальних громад у сфері надання адміністративних послуг; інклюзивність та універсальний дизайн, обслуговування різних груп клієнтів тощо [9].

Стратегія цифровізації публічного управління повинна включати діджиталізація державної служб; розвиток цифрових компетенцій державних службовців. Основними заходами для реалізації стратегії цифровізації є:

масштабне використання IКТ та цифрових технологій; 
формування новітнього дизайну навчального простору;

модернізація інфраструктурного оснащення;

впровадження нових технологічних і управлінських рішень;

використання технології онлайн-навчання із застосуванням цифрових освітніх ресурсів

За даними Аналітичного звіту Національне агентство України з питань державної служби за 2021 рік державні службовці категорії «Б» здебільшого визначили потребу у професійному навчанні за загальними короткостроковими програмами підвищення кваліфікації, що спрямовані на удосконалення таких професійних компетентностей, як: професійні знання 7498 осіб (25\%); впровадження змін - 3916 осіб (13,1\%); комунікація та взаємодія - 3729 осіб (12,4\%). Що стосується навчання державних службовців категорії «В» за загальними короткостроковими програмами підвищення кваліфікації - найбільша потреба визначена в удосконаленні таких професійних компетентностей, як: професійні знання - 25689 осіб $(33,5 \%)$; командна робота та взаємодія - 11304 осіб $(14,8 \%)$; цифрова грамотність - 10624 осіб $(13,9 \%)$ [10].

У формуванні цифрового суспільства важливим $є$ розуміння всіх контрагентів його розвитку (державних службовців, громадян, бізнесу), які результати Україна може отримати за умов успішної реалізації цифрових напрямів розвитку (табл.1)

Таблиия 1

Ключові результати від розвитку цифрових компетентностей

\begin{tabular}{|r|lr|rr|}
\hline \multicolumn{2}{|c|}{ Для держави } & \multicolumn{2}{|c|}{ Для громадян } & \multicolumn{2}{|c|}{ Для органів публічної } \\
влади
\end{tabular}

Стратегічне завдання системи освіти в сфері державного управління є: 
підготовка фахівців, що приймають рішення на основі даних, - Chief Data Officer (CDO), а також їх команди, які компетентні в управлінні даними, це i люди, що формують нову управлінську культуру, в якій: вітається ініціатива знизу, не діють жорсткі догми і алгоритми дій, а домінує ухвалення рішень на основі об'єктивних даних, переважаючим способом вирішення завдань $є$ не витрата державних коштів, а взаємовигідні партнерства, фокус уваги зосереджений на людині, а не на бюрократичних процедурах.

Для реалізації всіх завдань, які зосереджені на формуванні цифрових компетентностей, за реформою державного управління необхідно створити цифрову екосистему для держаних службовців та посадових осіб в органах державної влади та місцевого самоврядування. Цифрова екосистема розподілена, адаптивна, відкрита соціально-технічна система 3 властивостями самоорганізації, масштабованості та стійкості, подібна до природних екосистем, особливо в аспектах, пов'язаних 3 конкуренцією та співпрацею між різними сутностями [11].

Висновки. На основі проведеного дослідження, визначено, що розвиток цифрових навичок є головною умовою для розвитку цифрового суспільства будь-якої країни, пов'язана з усіма сферами функціонування суспільства та економіки. Доведено. що компетенція в сфері цифрових технологій повинна сприйматися як технічні знання та знання в когнітивних, соціальних та емоційних аспектах роботи в цифровому середовищі.

Узагальнено ключові навички в сфері цифрових технологій: використання технологій, моніторинг та контроль; аналітичне мислення та інновації; активне навчання та навчальні стратегії; комплексне вирішення проблем; критичне мислення та аналіз; креативність, оригінальність та ініціативність; лідерство та соціальний вплив, дизайн технологій та програмування; стійкість, стресостійкість та гнучкість; вміння аргументувати, вирішувати проблеми та створювати ідеї. Виділено основні напрямки компетенції в сфері цифрових технологій (вирішення проблеми, самоврядування, робота з людьми, використання технологій та їх розробка).

Доведено, що галузь цифрових навичок i компетенцій $\epsilon$ однією 3 найбільш неврегульованих в сфері гармонізації цифрових ринків через наявність таких проблем, як відсутність обліку високотехнологічної продукції, цифровізованих послуг, відсутність використання органами державної влади автоматизованих систем діловодства, відсутність наскрізних систем електронного документообігу, недостатній рівень розвитку концепції «мобільних» державних службовців 3 відповідними інструментами ефективної дистанційної роботи.

3 урахуванням ключових компонентостей трансформацій в організаціях публічного сектору (віддане лідерство, переконлива комунікація, чітка ціль та пріоритети, спроможності до впровадження змін, злагодженість та координація у впровадженні) визначено основні заходи для реалізації стратегії цифровізації: масштабне використання IКТ та цифрових технологій; формування новітнього дизайну навчального простору; модернізація інфраструктурного оснащення; впровадження нових технологічних i 
управлінських рішень; використання технології онлайн-навчання із застосуванням цифрових освітніх ресурсів, створення цифрової екосистеми для держаних службовців та посадових осіб в органах державної влади та місцевого самоврядування. Реалізація зазначених заходів дозволить досягти позитивних результатів від розвитку цифрових компетентностей для держави, для громадян, для органів публічної влади.

\section{Лimepamypa:}

1. Архипова С.О. Електронне урядування як форма як форма організації державного управління // Державне управління: удосконалення та розвиток. 2015, 5. http://www.dy.nayka.com.ua/?op=1\&z=855

2. Орлова Н.С., Майло В.В. Розвиток стратегічних комунікацій в органах публічної влади // Вчені записки Таврійського національного університету імені В.І. Вернадського. 2020. Т.31 (70). № 1. С.63-68.

3. Олексюк Л. В. Розвиток понятійно-категоріального апарату електронного доступу до публічної інформації та відкритих даних // Вісник НАДУ при Президентові України. 2016. №2. C. 36-43.

4. Орлова Н. Підготовка фахівців з публічного управління в умовах євроінтеграції України // Науковий журнал «Зовнішня торгівля: економіка, фінанси, право». 2019. №3(104). C.139-150.

5. Ukrainian National Platform of the Eastern Partnership Civil Society Forum. http://eap-csf.org.ua

6. Ferrari, A., DIGCOMP: A Framework for Developing and Understanding Digital Competence in Europe., EUR 26035, Publications Office of the European Union, Luxembourg, 2013

7. Проблеми та перспективигармонізації цифрового ринку України з ринками ЄС та країн СхП: аналітичний звіт. https://www.civic-synergy.org.ua/wp-content/ uploads/2018/04/ Problemy-ta-perspektyvygarmonizatsiyi-t

8. Деякі питання реформування державного управління України: розпорядження Кабінету міністрів України від 24 червня 2016 p. № 474-р. https://zakon.rada.gov.ua/laws/show/ru/474-2016-\%D1\%80\#Text

9.Звіт про виконання у 2020 році Стратегії реформування державного управління України. Київ: Кабінет міністрів України, 83 с.

10. Аналітичний звіт про індивідуальні потреби у професійному навчанні державних службовців на 2021 рік. Київ: Національне агентство України з питань державної служби, $37 \mathrm{c}$.

11. Про забезпечення реалізації деяких питань цифрового розвитку: наказ Державного агентства 3 питань електронного урядування України від 09.04.2019 № 24 . https://zakon.rada.gov.ua/rada/show/v0024883-19\#Text

\section{References:}

1. Arkhypova, Ye.O. (2015). Elektronne uriaduvannia iak forma iak forma orhanizatsiï derzhavnoho upravlinnia [E-government as a form as a form of organization of public administration]. Derzhavne upravlinnia: udoskonalennia ta rozvytok - Public administration: improvement and development, 5. (n.d.). dy.nayka.com.ua. Retrieved from http://www.dy.nayka.com.ua/?op=1\&z=855 [in Ukrainian].

2. Orlova, N.S. and Majlo, V.V. (2020). Rozvytok stratehichnykh komunikatsij v orhanakh publichnoi vlady [Development of strategic communications in public authorities]. Vcheni zapysky Tavrijs'koho natsional'noho universytetu imeni V.I. Vernads'koho - Scientific notes of 
Tavriya National University named after VI Vernadsky, 31 (70), vol.1, 63-68 [in Ukrainian].

3. Oleksiuk, L. V. (2016). Rozvytok poniatiy̆no-katehorial'noho aparatu elektronnoho dostupu do publichnoï informatsiï ta vidkrytykh danykh [Development of conceptual and categorical apparatus of electronic access to public information and open data]. Visnyk NADU pry Prezydentovi Ukraïny - Bulletin of the NAPA under the President of Ukraine, 2, 36-43 [in Ukrainian].

4. Orlova, N. (2019). Pidhotovka fakhivtsiv $\mathrm{z}$ publichnoho upravlinnia $\mathrm{v}$ umovakh ievrointehratsii Ukrainy [Training of specialists in public administration in the context of European integration of Ukraine]. Naukovyj zhurnal "Zovnishnia torhivlia: ekonomika, finansy, pravo» - Scientific Journal "Foreign Trade: Economics, Finance, Law", 3(104), 139-150 [in Ukrainian].

5. Ukrainian National Platform of the Eastern Partnership Civil Society Forum. (n.d.). eapcsf.org.ua. Retrieved from http://eap-csf.org.ua [in English]

6. Ferrari, A. (2013). DIGCOMP: A Framework for Developing and Understanding Digital Competence in Europe, EUR 26035, Publications Office of the European Union, Luxembourg, 2013 [in English]

7. Problemy ta perspektyvyharmonizatsii tsyfrovoho rynku Ukrainy z rynkamy YeS ta krain SkhP: analitychnyj zvit [Problems and prospects of harmonization of the digital market of Ukraine with the markets of the EU and Eastern countries: analytical report]. (n.d.). civicsynergy.org.ua. Retrieved from https://www.civic-synergy.org.ua/wp-content/uploads/2018/04/ Problemy-ta-perspektyvygarmonizatsiyi-t [in Ukrainian].

8. Rozporiadzhennia Kabinetu ministriv Ukrainy "Deiaki pytannia reformuvannia derzhavnoho upravlinnia Ukrainy” vid 24 chervnia 2016 roku. № 474-r [order of the Cabinet of Ministers of Ukraine "Some issues of public administration reform in Ukraine" from June 24, 2016 № 474-r]. (n.d.). zakon.rada.gov.ua. Retrieved from https://zakon.rada.gov.ua/laws/show/ru/474-2016-\%D1\%80\#Text [in Ukrainian].

9. Zvit pro vykonannia u 2020 rotsi Stratehii reformuvannia derzhavnoho upravlinnia Ukrainy [Report on the implementation in 2020 of the Public Administration Reform Strategy of Ukraine ], Kabinet ministriv Ukrainy, Kyiv [in Ukrainian].

10. Analitychnyj zvit pro indyvidual'ni potreby u profesijnomu navchanni derzhavnykh sluzhbovtsiv na 2021 rik [Analytical report on individual needs for professional training of civil servants for 2021], Natsional'ne ahentstvo Ukrainy z pytan' derzhavnoi sluzhby, Kyiv [in Ukrainian].

11. Nakaz Derzhavnoho ahentstva z pytan' elektronnoho uriaduvannia Ukrainy «Pro zabezpechennia realizatsii deiakykh pytan' tsyfrovoho rozvytkuz": vid 09 kvitnya 2019 roku № 24 [Order of the State Agency for e-Government of Ukraine "On ensuring the implementation of some issues of digital development” from April 09? 2019, №№ 24]. (n.d.). zakon.rada.gov.ua. Retrieved from https://zakon.rada.gov.ua/rada/show/v0024883-19\#Text [in Ukrainian]. 